(C) Ю.М. Фатула, Б.М. Пацкань, Л.Л. Варга, В.В. Ганчин, В.В. Машура, 2018

УДК $617.557-007.43-089$

\title{
Лікування пахвинних гриж лапароскопічним способом
}

\author{
Ю.М. Фатула ${ }^{1}$, Б.М. Пацкань ${ }^{1}$, Л.Л. Варга ${ }^{1}$, В.В. Ганчин ${ }^{2}$, В.В. Машура ${ }^{1}$ \\ y.fatula@gmail.com \\ ${ }^{1}$ Ужгородський національний університет; \\ ${ }^{2}$ Ужсгородська иентральна міська клінічна лікарня, Ужсгород
}

\section{Реферат}

Вступ. Сучасні методи хірургічного лікування пахвинних гриж пов'язані з широким впровадженням ненатяжних алопластичних, відкритих та лапароскопічних способів, що значно покращило віддалені результати, суттєво знизивши відсоток рецидивів гриж та виникнення синдрому хронічного післяопераційного пахвинного болю.

Мета дослідження. Проаналізувати безпосередні та віддалені результати лапароскопічних герніопластик при пахвинних грижах способом ТАРР.

Матеріали та методи. У хірургічній клініці Ужгородської центральної міської клінічної лікарні виконано 148 лапароскопічних герніопластик (ТАРР) у 135 хворих з пахвинними грижами.

Результати досліджень та їх обговорення. Серед інтраопераційних ускладнень у двох випадках мала місце кровотеча 3 нижньої епігастральної вени, що було успішно ліквідовано прошиванням та перев'язкою останньої. Післяопераційні ускладнення (гематома та інфільтрат післяопераційної рани) мали місце у $8(5,4 \%)$ випадках. Віддалені результати прослідковані у $92(68,1 \%)$ пацієнтів, серед яких хронічний пахвинний біль спостерігався у 3 (3,2\%) випадках, рецидив грижі виявлено у п’яти $(5,4 \%)$ пацієнтів.

Висновки. Лапароскопічні пахвинні алогерніопластики при відповідному матеріально-технічному забезпеченні та спеціальній професійній підготовці хірургів можуть бути альтернативою відкритим алогерніопластикам, переважаючи їх кращими безпосередніми та віддаленими результатами.

Ключові слова: пахвинні грижі, лапароскопічна трансабдомінальна преперитонеальна алогерніопластика, ТАРР, віддалені результати, герніопластика

\section{Laparoscopic repair of inguinal hernias}

Fatula ${ }^{1}$ Y.M., Patskan ${ }^{1}$ B.M., Varga ${ }^{1}$ L.L., Ganchin ${ }^{2}$ V.V., Mashura ${ }^{1}$ V.V. Uzhhorod National University, Medical Faculty, Uzhhorod ${ }^{l}$ Uzhhorod Central City Hospital, Uzhhorod ${ }^{2}$

Introduction. Modern methods of surgical treatment of inguinal hernias are associated with the wide introduction of non-persistent alloplastic, open, and laparoscopic methods, which greatly improved long-term results, significantly reducing the percentage of herniated recurrence and the occurrence of chronic post-operative inguinal pain syndrome.

The aim of the study. Analyze the direct and long-term results of laparoscopic inguinal hernias repair using TAPP.

Results and discussion. Among intraoperative complications in two cases there was a bleeding from the lower epigastric vein, which was successfully eliminated by fringing and dressing the latter. Postoperative complications (hematoma and postoperative wound infiltration) occurred in $8(5.4 \%)$ cases. Long-term results were observed in 92 (68.1\%) patients, including chronic inguinal pain in 3 (3.2\%) cases and recurrence of hernia was observed in five (5.4\%) patients.

Conclusions. Laparoscopic inguinal hernias repair with appropriate logistical support and specialist training of surgeons may be an alternative to open-ended mesh techniques, surpassing them with better direct and long-term results.

Key words: inguinal hernia, laparoscopic hernia repair, TAPP, long-term results

Вступ. Сучасні методи хірургічного лікування пахвинних гриж пов'язані з широким впровадженням ненатяжних алопластичних, відкритих та лапароскопічних способів, що значно покращило віддалені результати, суттєво знизивши відсоток рецидивів гриж та виникнення синдрому хронічного післяопераційного пахвинного болю [1-4]. За літературними даними, у США та країнах Свросоюзу лапароскопічні методики займають друге місце за частотою застосування при лікуванні пахвинних гриж після відкритих алогерніопластик, витіснивши «традиційні» аутопластичні операції $[2,5]$. Лапароскопічні алогерніопластики, маючи ряд важливих переваг (мала травматичність втручання, можливість виконання двобічних і симультанних операцій, мінімальний післяопераційний больовий синдром, зменшення післяопераційних ускладнень інфекційного характеру, швидша фізична і соціальна реабілітація, косметичний ефект), володіють і безумовними недоліками (необхідність загального знеболення, технічна складність і висока собівартість операції). Також не можна не відзначити обмежені можливості застосування лапароскопічних методик при невправимих, ковзних та защемлених грижах. Тому більшість хірургів обгрунтовано вважають лапароскопічні методики прерогативою спеціалізованих герніологічних центрів 3 висококваліфікованим кадровим складом $[3,4,6,7]$. Одним з чинників професійного оволодіння та, відповідно, ширшого впровадження лапароскопічних методик є вдосконалення й технічне спрощення етапів операції. 
Мета дослідження. Проаналізувати безпосередні та віддалені результати лапароскопічних герніопластик при пахвинних грижах способом ТАРР.

Матеріали та методи. У хірургічній клініці Ужгородської центральної міської клінічної лікарні виконано 148 лапароскопічних герніопластик (ТАРР) у 135 хворих 3 пахвинними грижами (у тринадцятьох пацієнтів була двобічна грижа). Чо- ловіків було 120 (88,9\%), жінок - 15 (11,1\%). За віковою ознакою хворих розподілили таким чином: 20-29 років - 12,5\%, 30-39 років - 21,9\%, 4049 років - 21,9\%, 50-59 років - 25\%, 60-69 років $15,6 \%, 70$ років і старше $-3,1 \%$.

Характеристика гриж за інтраопераційною класифікацією типів гриж за Gilbert-Rutkow наведена у таблиці 1.

Інтраопераційна характеристика пахвинних гриж за типом

Таблиця 1

\begin{tabular}{|l|l|c|c|}
\hline \multirow{2}{*}{$\begin{array}{c}\text { Tип } \\
\text { грижі }\end{array}$} & \multicolumn{1}{|c|}{ Інтраопераційна характеристика грижі } & \multicolumn{2}{c|}{ Кількість гриж } \\
\cline { 3 - 5 } & \multicolumn{1}{c|}{$\mathrm{n}$} & \multicolumn{1}{c|}{$\%$} \\
\hline I & Коса грижа 3 нерозширеним глибоким пахвинним кільцем & 35 & 23,6 \\
\hline II & Коса грижа з розширеним глибоким пахвинним кільцем & 38 & 25,7 \\
\hline III & Коса грижа зі зруйнованим глибоким пахвинним кільцем & 10 & 6,8 \\
\hline IV & Пряма грижа з великим дефектом задньої стінки пахвинного каналу & 14 & 9,5 \\
\hline V & Пряма грижа з невеликим дефектом задньої стінки пахвинного каналу & 32 & 21,6 \\
\hline VI & Комбінація косої і прямої гриж & 8 & 5,3 \\
\hline VII & Стегнова грижа & 5 & 3,4 \\
\hline VIII & Рецидивна грижа & 6 & 4,1 \\
\hline Всього & & 148 & 100 \\
\hline
\end{tabular}

Серед оперованих пацієнтів переважали хворі 3 косими пахвинними грижами (83 хв. $-56,1 \%)$. За вираженістю анатомічних змін більшість (105 хв. $77,8 \%$ ) становили хворі з невеликими пахвинними грижами (I, II, V типи).

Враховуючи лапароскопічний абдомінальний характер операції, проводили ретельне передопераційне обстеження пацієнтів для виявлення симультанної хірургічної або гінекологічної патології: обов'язково виконуємо ультразвукове дослідження органів черевної порожнини та малої миски, ФЕГДС.

За нашими модифікаціями (патент на корисну модель UA 71837 U від 25.07.2012 та патент на корисну модель UA 80875 U від 10.06.2013), котрі удосконалюють етап фіксації сітки та останній етап ТАРР - перитонізацію сітки очеревиною. Для перитонізації сітки відшарований нижній клапоть очеревини фіксують до черевної стінки не скобками-фіксаторами за допомогою герніостеплера, а шляхом накладання спеціальних «пункційних» швів. Цей оперативний прийом виконують шляхом пункцій через точкові розрізи шкіри всіх шарів передньої черевної стінки спеціальним інструментом із заправленою в ньому лігатурою (пункційнозшиваючою голкою), з наступним інтраабдомінальним проколюванням і фіксацією верхнього краю відшарованого клаптя очеревини. При повторній пункції через попередній точковий розріз вільною (без лігатури) голкою лігатуру, що фіксує очеревину, захоплюють, виводять назовні (на передню черевну стінку) і зав'язують таким чином, що вузол залишається під шкірою. Для достатньої фіксації очеревини 3 метою прикриття нею сіткиімплантата вистачає накладання 3-4 «пункційних» швів. Точкові розрізи шкіри для пункцій виконують по умовній лінії між лоном та spina iliaca anterior superior, відступаючи від них на 3-4 см. Дану методику використано у 85 випадках.

Розмір імплантованої сітки становив не менше $8 \times 13$ см (у більшості пацієнтів - 10x13 см). Перевагу надаємо «легким» сіткам іноземного виробництва.

Перебування у стаціонарі після операції становило від 2 до 6 днів, у середньому 2,6士0,8 дня.

Результати досліджень та їх обговорення. Аналізуючи безпосередні та віддалені результати лікування, ми отримали такі дані.

У двох випадках $(1,4 \%)$ мали місце інтраопераційні ускладнення у вигляді пошкодження нижньої епігастральної вени, яка була лапароскопічно прошита та перев’язана.

Післяопераційний період у всіх пацієнтів протікав гладко, хворі не потребували введення наркотичних анальгетиків, вставали в день операції.

Післяопераційні ускладнення (гематома та інфільтрат післяопераційної рани) мали місце у 8 $(5,4 \%)$ випадках.

Віддалені результати (за період від 3 місяців до 6,5 року) прослідковано у $92(68,1 \%)$ пацієнтів. Хронічний пахвинний біль різної інтенсивності спостерігався у трьох (3,2\%) хворих. Рецидив грижі виявлено у п'яти $(5,4 \%)$ випадках.

Наш невеликий, але позитивний досвід лапароскопічних пахвинних алогерніопластик дозволяє зробити висновок про необхідність відбору хворих для цієї оперативної методики: кращі інтра- та післяопераційні результати спостерігаються у пацієнтів 3 невеликими пахвинними грижами (I, II, V типи за класифікацією Gilbert-Rutkow). 
Висновки. Лапароскопічні пахвинні алогерніопластики при відповідному матеріально-технічному забезпеченні та спеціальній професійній підготовці хірургів можуть бути альтернативою відкритим алогерніопластикам, переважаючи їх кращими безпосередніми та віддаленими результатами.

Інформація про конфлікт інтересів. Автори заявляють про відсутність конфлікту інтересів при виконанні наукового дослідження та підготовці даної статті.

Інформація про фінансування. Автори гарантують, що вони не отримували жодних винагород в будь-якій формі, здатних вплинути на результати роботи.

Особистий внесок кожного автора у виконання роботи:

Фатула Ю.М. - розробка концепції і дизайну дослідження, аналіз отриманих даних, редагування;

Пацкань Б.М. - збір матеріалу дослідження, аналіз отриманих даних, підготовка тексту статті;

Варга Л.Л. - збір матеріалу дослідження, аналіз отриманих даних, підготовка тексту статті;

Ганчин В.В. - збір матеріалу дослідження, аналіз отриманих даних, підготовка тексту статті;

Машура В.В. - збір матеріалу дослідження, аналіз отриманих даних, статистична обробка даних.

\section{Список використаної літератури}

1. Sajid MS, Kalra L, Parampalli U, et al. A systematic review and meta-analysis evaluating the effectiveness of lightweight mesh against heavyweight mesh in influencing the incidence of chronic groin pain following laparoscopic inguinal hernia repair. Am J Surg 2013; 205:726.

2. Bilianskyi LS, Perekhrestenko OV, Svisenko OV, Davydenko NH. Porivnialnyi analiz metodiv vidkrytoi ta laparoskopichnoi aloplastyky pakhvynnoho kanalu. Khirurhiia Ukrainy. 2011;3:7-9. [In Ukrainian]

3. Bansal VK, Misra MC, Babu D, Victor J, Kumar S, Sagar R, Rajeshwari S, Krishna A, Rewari V. A prospective, randomized comparison of long-term outcomes: chronic groin pain and quality of life following totally extraperitoneal (TEP) and transabdominal preperitoneal (TAPP) laparoscopic inguinal hernia repair. Surg Endosc. 2013;27(7):2373-82.

4. Feleshtynskyi YaP, Svyrydovskyi SA. Otsinka efektyvnosti riznykh sposobiv aloplastyky pry pakhvynnykh hryzhakh. Khirurhiia Ukrainy. 2011;3:111-3. [In Ukrainian]

5. Rosenberg J, Bisgaard T, Kehlet H, Wara P, Asmussen T, Juul P et al. Danish hernia database recommendations for the management of inguinal and femoral hernia in adults. Dan Med Bull. 2011;58:C4243.

6. Salma U, Ahmed I, Ishtiaq S. A comparison of post-operative pain and hospital stay between Lichtenstein's repair and Laparoscopic Transabdominal Preperitoneal (TAPP) repair of inguinal hernia: A randomized controlled trial. Pak J Med Sci. 2015;31(5):1062-6.

7. Nichitajlo ME, Bulik II. Sovremennye aspekty jendovideohirurgicheskogo lechenija slozhnyh i recidivnyh pahovyh gryzh. Klin. hirurgija. 2010;3:10-6. [In Russian]

\section{Стаття надійшла до редакції: 11.01 .2018 р.}

